Journal of Advanced Research in Fluid Mechanics and Thermal Sciences

Journal homepage: www.akademiabaru.com/arfmts.html ISSN: 2289-7879

\title{
Combination of Dehumidifier, Heat Pump and Air Heater: Influence of Temperature, Specific Humidity, And Mass Flow Rate of Air on Specific Energy Consumption
}

\author{
Ahmad Zikri ${ }^{1}$, Engkos Achmad Kosasih ${ }^{1,}$, Muhammad Irfan Dzaky ${ }^{1}$, Firdaus ${ }^{1}$ \\ 1 Department of Mechanical Engineering, Faculty of Engineering, Universitas Indonesia, Kampus UI Depok 16424, West Java, Indonesia
}

\section{ARTICLE INFO}

\section{Article history:}

Received 19 December 2019

Received in revised form 26 May 2020

Accepted 1 June 2020

Available online 9 October 2020

Keywords:

Drying; specific energy consumption; relative humidity; refrigeration; heat pump

\section{ABSTRACT}

Drying is the process of transferring heat and mass to remove water by heat application, from solid or liquid food, to decrease water content. The temperature and drying conditions imposed on a product have an essential influence on it. Drying in high temperatures can cause damage the sensitive materials. To overcome this problem, in this paper, to show the effect of temperature, specific humidity and mass flow rate, on the specific energy consumption on the use of air heaters, and the combination refrigeration system to produce hot and dry air. In this study, we use an experimental method by using temperature variations of $60^{\circ} \mathrm{C}, 90^{\circ} \mathrm{C}, 120^{\circ} \mathrm{C}$, and $150^{\circ} \mathrm{C}$. Air mass flow rates using $100 \mathrm{Lpm}, 150 \mathrm{Lpm}, 200 \mathrm{Lpm}$, and $250 \mathrm{Lpm}$ variation. The air from the environment is sucked up by the blower and then enters the evaporator. In the evaporator, the air will condensate so the air will get the low relative humidity. The heat in the condenser is used as preheating the dry air before entering the heater. To produce hot and dry air with the minimum humidity ratio $(3.9 \mathrm{~g} / \mathrm{kg}$ dry air $)$ for the same target temperature is recommended to use a $100 \mathrm{Lpm}$ airflow rate by adjusting the evaporator pressure to 2.6 bar. Then, to obtain the minimum SECR (0.928), the recommended target temperature is $120^{\circ} \mathrm{C}$, by adjusting the airflow rate to $250 \mathrm{Lpm}$ and the pressure at the evaporator 1.6 bar.

\section{Introduction}

In recent years, many fruits have been processed to facilitate the process of consumption, one example is in the form of fruit juice. However, this has the disadvantage of being able to change color to brown because it requires a longer and heavier time for the distribution process related to the water reserves needed in the juice or fruit juice. Another form of processing to solve the existing problem with the form of powder with the process of drying [1]. Drying is the process of transferring

\footnotetext{
${ }^{*}$ Corresponding author.

E-mail address: kosri@eng.ui.ac.id

https://doi.org/10.37934/arfmts.76.1.124134
} 
heat and mass to remove water by heat application, from solid or liquid food, intending to obtain solid products that are low enough in water content [2].

The main objective of any drying process is to produce a dried product of the desired quality at a minimum cost and maximum throughput by optimizing the design and operating conditions. Spray Drying is a type of dryer used to evaporate and dry the solution and slurry to obtain the results of a dry solid [3]. This technology uses drying temperatures above $100^{\circ} \mathrm{C}$ [4]. High-temperature air dryers reduce the moisture content in the material. The higher the air temperature in the drying chamber, the faster the material dries [5]. The more heat exposed to the material, the faster the material dries [6]. The temperature and drying conditions imposed on a product have an important influence on it. Drying temperatures in spray drying are a common problem during the drying process. Drying in high temperatures can cause damage the sensitive materials [7]. Drying materials using high drying air temperatures can damage products in heat-sensitive materials, such as vitamins, proteins, and $\beta$ carotene [8]. Food that is sensitive to heat cannot accept physical, chemical, microbiological, and mechanical treatment, when it is dried using high degrees of temperature, such as drying in a spray dryer [9]. Because of the high operating temperature, this spray drying technology cannot be used on heat-sensitive materials [10]. By drying the material at a low temperature, the energy consumption needed to generate power heater will also be lower. Based on energy scenario modeling for Malaysia using LEAP has been carried out to develop a long-term and sustainable energy sector scenario for Malaysia, there are several policies to address energy consumption in Malaysia resulting from an increase in population each year. This increase in energy consumption will also result in environmental pollution which makes $\mathrm{CO}_{2}$ emissions increasing as well. Therefore, the importance of a tool to achieve maximum efficiency to overcome energy problems [11].

The ideal drying air temperature for heat-sensitive material is in the temperature range of 50$60^{\circ} \mathrm{C}$. However, this method has shortcomings in terms of performance resulting from increased temperatures which can cause damage to vitamins, proteins, and $\beta$-carotene. on the type of material to be dried, as well as the sugar content that can be determined the reduction in glass temperature. In addition, the drawback is the low efficiency of large energy consumption [12]. The process of drying a material occurs through two processes, namely the heating process and the drying process. Drying is done to reduce the amount of water by mechanical conditions of temperature, $\mathrm{RH}$, and airflow control, without damaging the structure of the product.

A heat pump is a device that can generate heat besides coal-fired boilers and heater. The heat pump system includes an air source heat pump and a solar heat pump [13]. Currently, the use of Waste Heat Recovery (WHR) in applied technology to process food is increasingly being investigated, especially for the drying process. For instance, In soy protein powder factories, an effective heat recovery system is needed to reduce energy consumption. For spray drying and space heating during the heating season, circular water with a heat pump is used to recover waste heat from the exhaust air to preheat the air around the inlet. Drosou et al., [14] has found that the heat recovery system could reach $21.3 \%$ energy-saving amount compared to the traditional spray drying system. And the static payback period of the heat recovery system is around 2.4 years [14]. In general, there are several types of drying technology used in food processing. Extra energy is needed to encourage an efficient drying process to reduce system energy consumption. This research on modifying the heat pump system and combining other mechanisms to improve the performance of the heat pump system has been done widely. Heat pump dryer is proven as a drying system that ensures the product's quality especially food and agriculture products, able to control drying temperature, relative humidity, moisture contain extraction, drying air velocity, drying period, etc [15].

Applications for heat pump systems are widely used in space heating and cooling, desalination, and drying. For instance, in tomato flavour from a heat pump dehumidifier dryer was characterized 
and compared to fresh and freeze-dried tomato samples for the retention of fresh flavour compounds [16]. Nonvolatile, volatile, and odor intensity are quality parameters that will be monitored. In the non-volatile profile, there is no difference but there is a significant change in the volatile impact of the main odor observed. On the other hand, commercial spray-dried tomatoes are also evaluated to check thermally induced volatile changes. The volatile and sensory profiles of heat pump dried tomato were comparable to freeze-dried tomato, with good retention of fresh aroma.

Operation energy consumption of heat pump systems is one of the key problems for system design [17]. The main advantages of using HP technology are the energy-saving potential and the ability to control drying temperature and air humidity. This creates the possibility of a wide range of drying conditions [18]. Using a heat pump dryer, which is a combination of heat pump and drying unit, both the latent heat and sensible heat can be recovered from the exhaust air, thus improving the overall thermal performance and yielding effective control of air conditions at the inlet of the dryer. The combination of spray dryers with electric air heaters and cooling systems has proven to be efficient in terms of energy consumption [19]. The combination of spray dryer and cooling system with double condenser using R134a cooler. The cooling system is supported by the amount of heat energy that is wasted from the refrigerant condensation step, which can increase engine efficiency and increase productivity [20].

Experiments on the combination of spray dryers and refrigeration systems have been carried out at an airflow rate of $450 \mathrm{Lpm}$ and drying air temperature at $60^{\circ} \mathrm{C}$ with a refrigeration system at a humidity ratio of $0.005(\mathrm{~kg} \mathrm{H} 2 \mathrm{O} / \mathrm{kg}$ dry air), resulting in a drying capacity equal to the capacity drying at a drying air temperature of $120^{\circ} \mathrm{C}$ without a refrigeration system at a humidity ratio of $0.021 \mathrm{~kg}$ $\mathrm{H}_{2} \mathrm{O} / \mathrm{kg}$ dry air). For an airflow rate of $450 \mathrm{Lpm}$, drying capacity at $90^{\circ} \mathrm{C}$ with a refrigeration system at a humidity ratio of 0.005 ( $\mathrm{kg} \mathrm{H}_{2} \mathrm{O} / \mathrm{kg}$ dry air) produces a drying capacity of 1.5 times the drying capacity at $120^{\circ} \mathrm{C}$ drying air temperature $\mathrm{C}$ without a refrigeration system at a moisture ratio of 0.021 ( $\mathrm{kg} \mathrm{H}_{2} \mathrm{O} / \mathrm{kg}$ dry air) [21]. This shows that the system can reduce the temperature of the drying air without reducing production capacity. By regulating the temperature of air that passes through the evaporator at $10^{\circ} \mathrm{C}$, the drying temperature at $140^{\circ} \mathrm{C}$, and the airflow rate at $450 \mathrm{Lpm}$, the productivity of drying with a cooling system is even 3 times greater than the yield of drying productivity with conventional methods [22].

In other studies, the energy analysis of a cooling system with multistage evaporative coolers using liquid desiccant dehumidifier between the stages [23]. The researched evaporative cooling system utilizes the air humidity for cooling in humid areas and requires no additional water supply. In this cooling system, energy to regenerate a weak drying fluid is the main energy needed. In this study, the heat input for regeneration is supplied from conventional energy sources such as a simple line heater. The results show that the energy consumption is about $25 \%$ less for the mechanical regeneration system with $3 \%$ recovery than the thermal energy regeneration system to increase the desiccant solution temperature of $22^{\circ} \mathrm{C}$. The COP of the proposed cooling system is defined as the cooling effect by the mass rate of water evaporated in the system divided by the amount of energy supplied to the system, that is the COP is independent of the energy source.

The condenser produces waste heat reaches $90^{\circ} \mathrm{C}$ and the heat is accumulated into a space heater up to $140^{\circ} \mathrm{C}$. That means: the heater works only up to $50^{\circ} \mathrm{C}$, so the temperature of the air is high and dry but has a very low SECR (Ratio of Specific Energy Consumption) in dew point $20^{\circ} \mathrm{C}$, which indicates that the system is very significant [24]. In a study conducted by Kosasih et al., [24], combining spray dryers with a dehumidifier system based on a refrigeration system with an air heater to increase the humidity of the air by increasing the level of air condensation to reduce the water content will be reduced. The refrigeration system is composed of an evaporator that functions as a dehumidifier; the hermetic compressor works to increase the pressure, then turns on two condensers arranged in 
parallel as preheaters and economizers. By utilizing the heat coming out of the condenser, which will be used to increase the temperature of the air before entering the air dryer and expansion valve. Condensers that function as economizers can prevent the exergy of the system so that it can increase system efficiency. The combination of this system can reduce the use of energy/specific energy released from the whole system 39\%, combined with a spray dryer system with a cooler $39 \%$, compared to a spray dryer system without a dehumidifier.

The ability of a heat exchanger is needed to obtain an effective heat transfer. But the ability of the heat exchanger is also affected by the working fluid in a heat exchanger. Based on the results of research conducted by Lee [25], showed that the efficiency of domestic water heat exchangers is optimal when 1.5\% copper or alumina nanoparticles are added to a water-based heat transfer liquid. The results also show that the addition of copper or alumina nanoparticles to a water-based heat transfer liquid increases the temperature of domestic hot water. Copper nanoparticles significantly increase the temperature of domestic hot water. The application of nanofluid as a strong candidate to increase heat transfer in domestic water heating systems was found in this study [25].

The drying productivity with the refrigeration system is even 3 times larger than the result of the drying productivity with the conventional method. These results indicate that the combination of spray drying and refrigeration systems with low evaporator temperatures can have a significant positive impact [26]. In a study conducted by Ruhyat et al., [26], the dehumidifier system based on a refrigeration system uses two condensers arranged in series and uses a hermetic compressor that has a power of $0.5 \mathrm{PK}$, specific energy consumption at a flow rate of $450 \mathrm{Lpm}$ at a dew point of $100^{\circ} \mathrm{C}$ over a low dehumidifier energy consumption. However, this refrigeration system has a low coefficient of performance (COP).

Today, conventional drying processes are often carried out when pre-harvesting, postharvest handling, and thermal processing. But it significantly affects the typical fresh fruit colour, aroma, and overall taste due to high temperatures or prolonged exposure to heat and oxygen. Technologies such as freeze-drying, where low temperatures are used, may preserve quality better than other techniques but are prohibitively expensive and time-consuming [27]. Hence, there is a significant opportunity for developing economically viable technologies to produce high-quality flavour ingredients.

In a previous study, drying using a spray dryer system with a dehumidifier system based on a refrigeration system with an air heater. The current research aims to produce hot dry air using a double condenser refrigeration system arranged in series. This refrigeration system aims to condense air into the referrer system evaporator so that the water content in the air becomes lowest. Then by using this system can reduce energy consumption by utilizing the heat condenser on the refrigeration system that functions as a preheater.

\section{Methodology}

In this research, we are using the experimental method in the controlled room with the air temperature $27,3^{\circ} \mathrm{C}$ and $\mathrm{RH}=81,8 \%$. The schematic diagram of the experiment shown in Figure 1 below. 


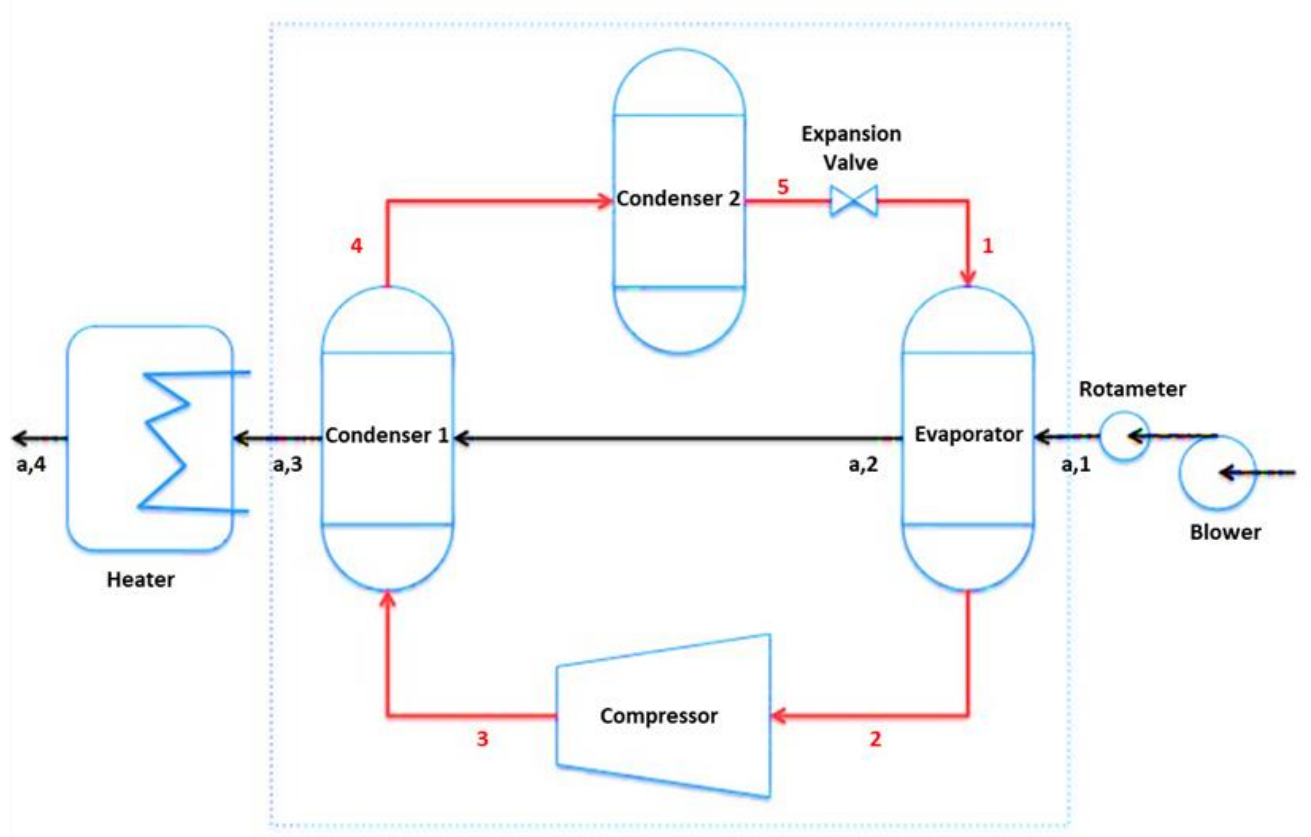

Fig. 1. Schematic diagram of the experiment

The goal of this research is to produce hot dry air (by dehumidifying the air in the evaporator of a refrigeration system). The relative humidity and the dry bulb temperature of the air (at the inlet, point a1, and outlet, point a2, of the evaporator) are measured by using thermocouple K-type and collected by using DAQ NI 9213. Air temperature at the outlet of the condenser 1 (at point a3) is measured by NI-DAQ 9213. At the outlet of an electric air heater (point a4) the temperature of the air is measured by NI-DAQ 9213 and controlled by using Shimaden PID controller. The temperature of the heater was varied at $60^{\circ} \mathrm{C}, 90^{\circ} \mathrm{C}, 120^{\circ} \mathrm{C}$, and $150^{\circ} \mathrm{C}$. The air mass flow rates also varied $100 \mathrm{Lpm}$, $150 \mathrm{Lpm}, 200 \mathrm{Lpm}$, and $250 \mathrm{Lpm}$ and measured by using rotameter. The air mass flow variation controlled by a voltage regulator that connected to the blower. The power of an electric air heater is calculated, and the power of the compressor refrigeration system is measured by using a power meter.

The dehumidifier is the evaporator of the refrigeration system that uses R-134a refrigerant. The refrigeration system is using two condensers that arranged in series. The function of condenser 1 is heat recovery apparatus that recovers part of compressor power and air heat loss in the evaporator. The rest of the heat of the refrigerant is released to the environment through the condenser 2.

The air has a specific humidity value from the magnitude of the relative humidity value. This can be formulated into the equation as follows

$\dot{m}_{a}=\dot{m}_{d a}+\dot{m}_{v}$

Then the equation is divided by the mass flow rate of dry air

$\frac{\dot{m}_{a}}{\dot{m}_{d a}}=1+\frac{\dot{m}_{v}}{\dot{m}_{d a}}$

$\omega$ is the ratio between the mass flow rate of vapor and the mass flow rate of dry air, then

$\dot{m}_{d a}=\frac{\dot{m}_{a}}{1+\omega}$ 
To calculate the heat released on the evaporator, you can use the following equation

$$
\left(\dot{m}_{d a} h_{a, 1}\right)=Q_{\text {evap }}+\left(\dot{m}_{w} h_{w}\right)+\left(\dot{m}_{d a} h_{a 2}\right)
$$

where $h_{a 1}$ is the environmental enthalpy of the air, $h_{a 2}$ the evaporator air enthalpy, $\dot{m}_{w}$ is the mass of evaporating water dan $h_{w}$ is the evaporating enthalpy.

$$
\begin{aligned}
& \dot{m}_{w}=\dot{m}_{v 1}-\dot{m}_{v 2} \\
& \dot{m}_{v}=\dot{m}_{d a} \omega_{a}
\end{aligned}
$$

To calculate the refrigerant mass flow rate can use the following formula

$\eta_{m} \eta_{e} P_{c o m p}=\dot{m}_{r}\left(h_{3}-h_{4}\right)$

which

$P_{\text {comp }}=V I \cos \varphi$

From Eq. (7), the heat released in the evaporator can be calculated through the equation below

$Q_{\text {evap }}=\dot{m}_{r}\left(h_{2}-h_{1}\right)$

To calculate the heat released from condenser 1 , can use the following equation

$$
Q_{c 1}=\dot{m}_{d a}\left(h_{a 3}-h_{a 2}\right)
$$

To calculate the magnitude of the enthalpy change from condenser 1 , can use the following equation

$Q_{c 1}=\dot{m}_{r}\left(h_{3}-h_{4}\right)$

To calculate the magnitude of the enthalpy change from condenser 2 , can use the following equation

$Q_{c 2}=\dot{m}_{r}\left(h_{4}-h_{5}\right)$

To calculate specific energy consumption (SEC) using the dehumidifier, can use the following equation

$S E C=\frac{P_{c o m p}+P_{f a n}+P_{h}+P_{b}}{\dot{m}_{d a}}$

For systems without dehumidification (heater only) $P_{c o m p}=0$ and $P_{f a n}=0$. To calculate the power in the heater using the following equation 
$P_{h}=\dot{m}_{d a} C_{p}\left(T_{a 4}-T_{h, i n}\right)$

$T_{h, i n}=T_{a 3}$ (for the system using dehumidifier), $T_{h, i n}=T_{a 1}$ (for the system using heater only). Then to calculate the ratio of specific energy consumption using the following equation

$R_{S E C}=\frac{S E C_{\text {Dehumidifier }}}{S E C_{\text {Without Dehumidifeir }}}$

\section{Results}

In this experiment, the relationship of the specific energy consumption ratio $\left(R_{S E C}\right)$ to produce hot dry air by using dehumidifier combine with heater and only using the heater for the temperature $60^{\circ} \mathrm{C}, 90^{\circ} \mathrm{C}, 120^{\circ} \mathrm{C}$, and $150^{\circ} \mathrm{C}$ can be seen in the following Figure 2.

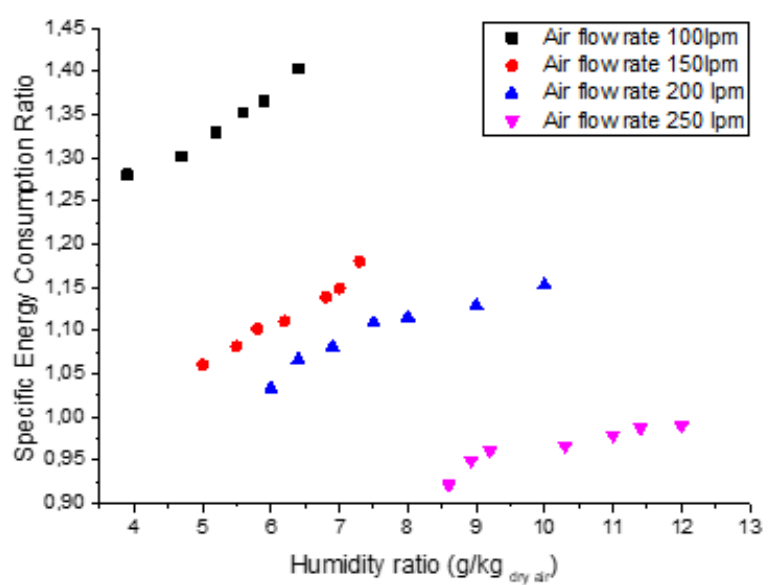

(a)

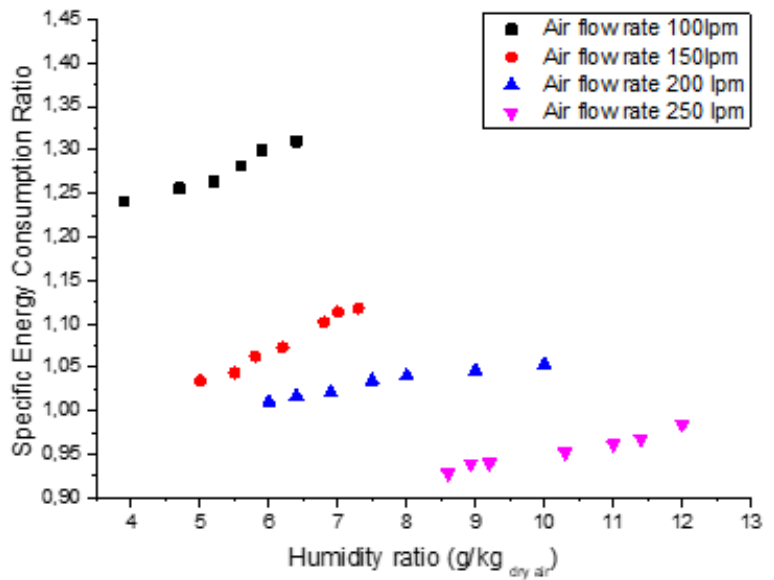

(c)

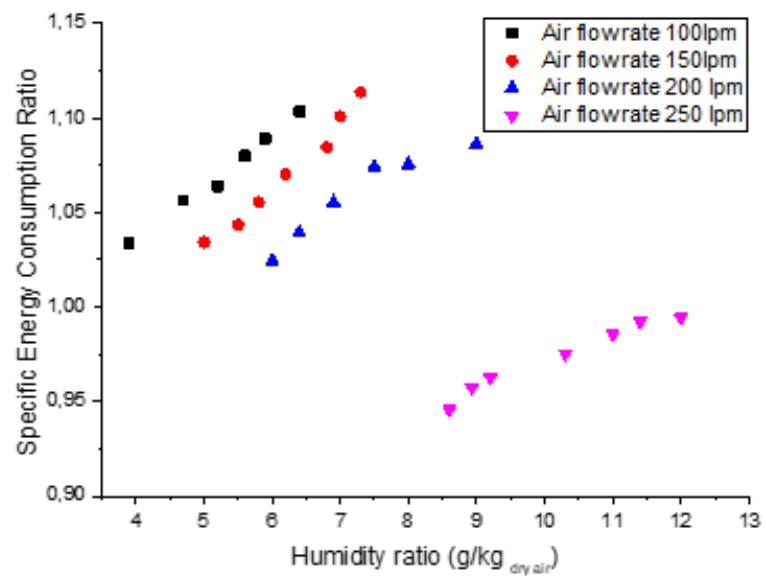

(b)

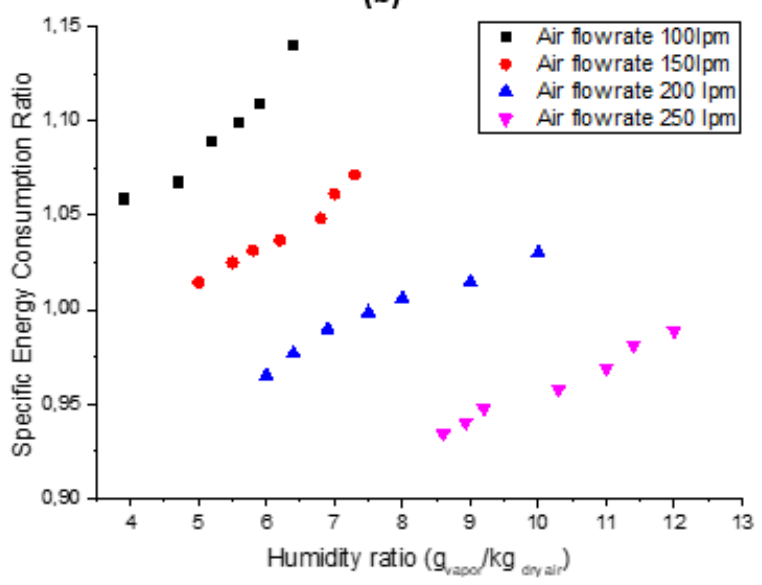

(d)

Fig. 2. Graph Specific Energy Consumption Ratio vs Humidity ratio at Temperature (a) $60^{\circ} \mathrm{C},(\mathrm{b}) 90^{\circ} \mathrm{C}$, (c) $120^{\circ} \mathrm{C}$, and (d) $150^{\circ} \mathrm{C}$ for different air flow rate

Based on the picture above, in Figure 2(a)-(d) it can be concluded that the relationship of the ratio of specific energy consumption at each heating temperature is influenced by the given air discharge. When the airflow rate is $250 \mathrm{Lpm}$, the value of the specific energy consumption ratio is the lowest compared to other airflow rates. So, by using a dehumidifier system, when the airflow rate is 250 Lpm, the SEC is lower if it only uses a heater. In certain conditions, when the airflow rate used is 200 $\mathrm{Lpm}$ and $250 \mathrm{Lpm}$ with a temperature of $150^{\circ} \mathrm{C}$ the value of the specific energy consumption ratio is 
lower than other air flow rate. It means that energy consumption using a dehumidifier system is still more efficient than just using a heater.

When the $R_{S E C}$ value more than 1 indicates that at the same airflow and the same temperature target of the heater, the SEC value of dehumidifier system is higher than without the dehumidifier system. When the $R_{S E C}$ value less than 1 indicates that at the same airflow and the same temperature target of the heater, the energy consumption by using the dehumidifier system is lower than only using the heater. $r$. This is because when the dry air comes out the condenser 1 is preheating so that the energy to raise a certain temperature will be smaller.

Figure 3 illustrates the relationship between Evaporator pressure and humidity ratio. To get a lower humidity ratio, it also requires pressure on the low evaporator as well. For the same evaporator pressure, the lower the airflow rate, the lower the humidity ratio obtained. The low airflow rate causes the incoming air will be more easily to condensation on the evaporator refrigeration system so that the air coming out of the evaporator becomes drier. When at a lower airflow rate, want to produce air with a lower humidity ratio by lowering the pressure on the evaporator (with the expectation of a lower SECR), this condition will be difficult to achieve because the evaporator may freeze, which can inhibit heat exchange.

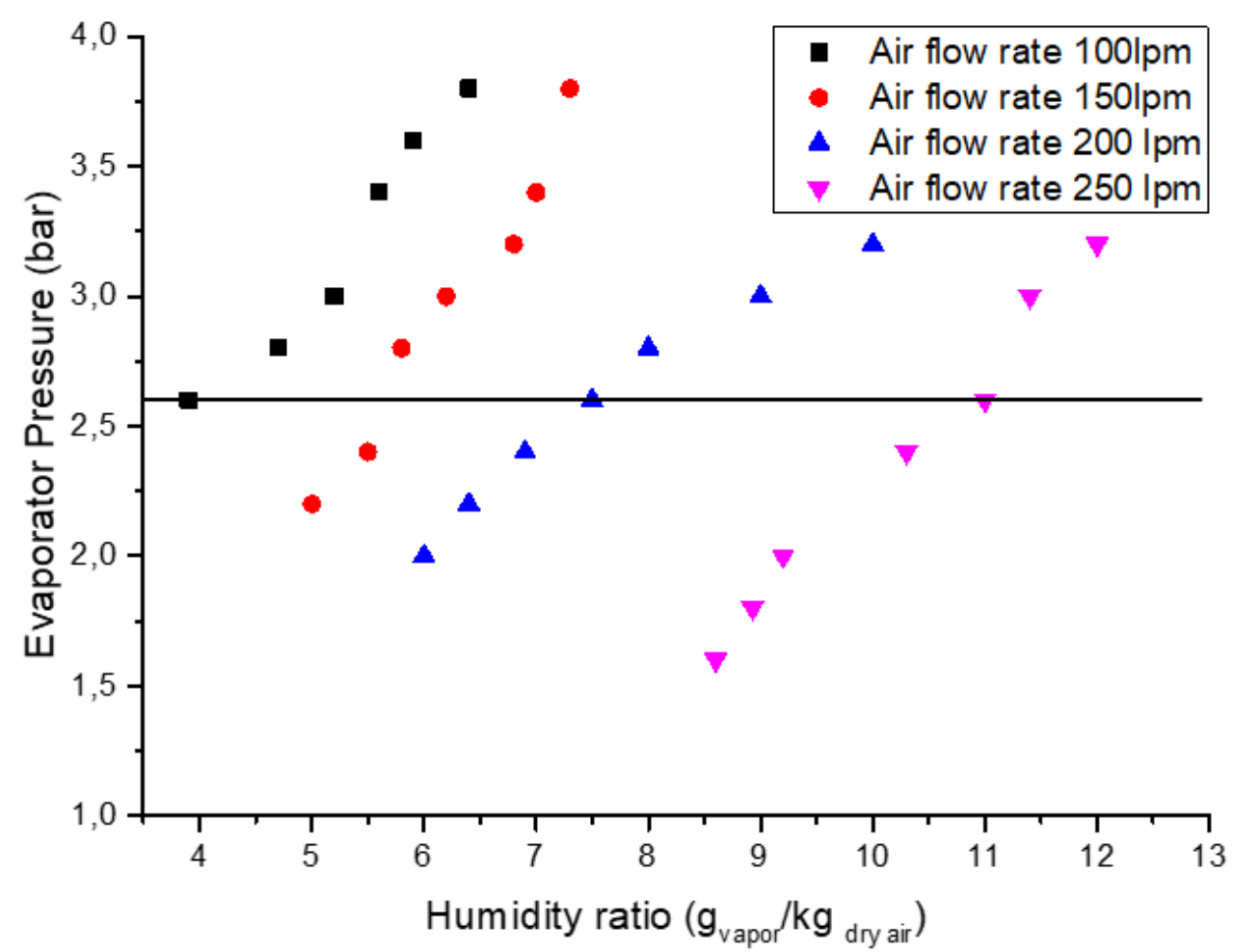

Fig. 3. Graph Evaporator pressure vs Humidity ratio

Based on the psychometric chart in Figure 4, at point, a, 1 is an environmental air condition with a temperature of $27.3^{\circ} \mathrm{C}$ and $\mathrm{RH}=81.8 \%$. Furthermore, air will enter the evaporator in the refrigeration system so that the $\mathrm{RH}$ increases with decreasing air temperature. However, the air produced does not reach $100 \% \mathrm{RH}$ because when condensation occurs in the evaporator tube, some of the water will evaporate and be carried by dry air again so that the RH measured at point a, 2 is $88 \%$. The air will flow into condenser 1 and an increase in temperature up to $50^{\circ} \mathrm{C}$. then the air will enter the electric heater and require a little energy to produce dry air with a temperature of $60^{\circ} \mathrm{C}$. 


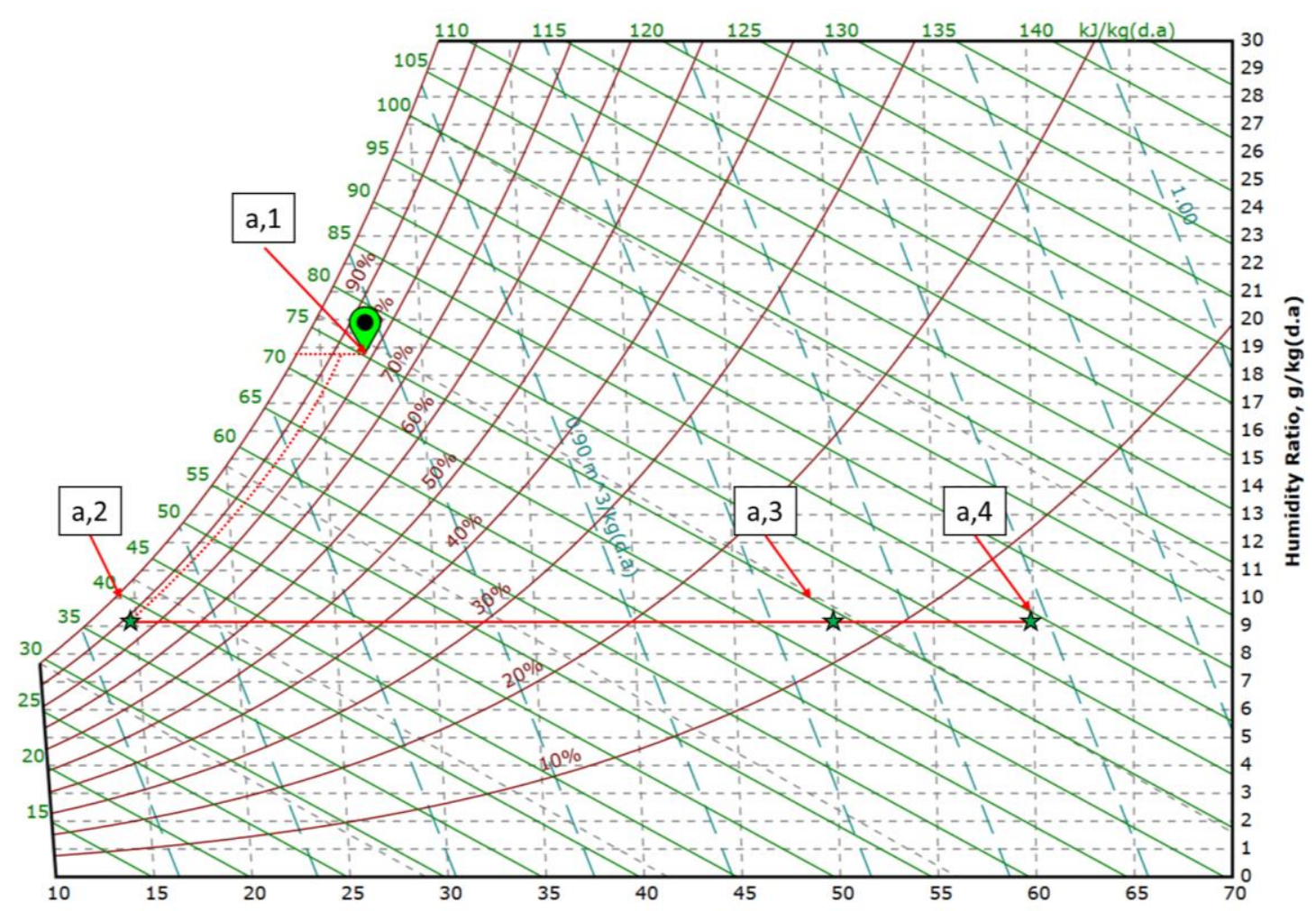

Fig. 4. Psychometric chart for airflow rate $250 \mathrm{Lpm}$ by using a dehumidifier system

\section{Conclusions}

Overall, it can be concluded that to produce air with a minimum humidity ratio ( $3.9 \mathrm{~g} / \mathrm{kg}$ dry air) for the same target temperature, it is recommended to use a $100 \mathrm{Lpm}$ airflow rate by adjusting the evaporator pressure to 2.6 bar. To obtain the minimum $R_{S E C}(0.928)$, the recommended temperature is $120^{\circ} \mathrm{C}$, by adjusting the airflow rate to $250 \mathrm{Lpm}$ and the pressure at the evaporator 1.6 bar.

\section{Acknowledgement}

This research was sponsored by PITTA A funding (NKB-0461/UN2.R3.1/HKP.05.00/2019) from the Directorate of Research and Community Service (DRPM) Universitas Indonesia. Also, the authors are grateful to Universitas Indonesia for facilities and management support.

\section{References}

[1] Sousa, Alexandre Santos de, Soraia Vilela Borges, Natália Ferreira Magalhães, Hevandro Vaz Ricardo, and Aline Damico Azevedo. "Spray-dried tomato powder: reconstitution properties and colour." Brazilian Archives of Biology and Technology 51, no. 4 (2008): 607-614. https://doi.org/10.1590/S1516-89132008000400019

[2] Kumar, Yashwant, Soumitra Tiwari, and Seema A. Belorkar. "Drying: An excellent method for food preservation." International Journal of Engineering Studies and Technical Approach 1, no. 8 (2015): 1-17.

[3] Sun, Lan, Md Raisul Islam, J. C. Ho, and A. S. Mujumdar. "A diffusion model for drying of a heat sensitive solid under multiple heat input modes." Bioresource Technology 96, no. 14 (2005): 1551-1560. https://doi.org/10.1016/i.biortech.2004.12.016

[4] Liu, Fengxia, Xiamin Cao, Houyin Wang, and Xiaojun Liao. "Changes of tomato powder qualities during storage." Powder Technology 204, no. 1 (2010): 159-166. https://doi.org/10.1016/i.powtec.2010.08.002

[5] Langrish, T. A. G., and D. F. Fletcher. "Spray drying of food ingredients and applications of CFD in spray drying." Chemical Engineering and Processing: Process Intensification 40, no. 4 (2001): 345-354. https://doi.org/10.1016/S0255-2701(01)00113-1 
[6] Fletcher, D. F., Baoyu Guo, D. J. E. Harvie, T. A. G. Langrish, J. J. Nijdam, and Jennifer Williams. "What is important in the simulation of spray dryer performance and how do current CFD models perform?." Applied Mathematical Modelling 30, no. 11 (2006): 1281-1292.

https://doi.org/10.1016/i.apm.2006.03.006

[7] Kosasih, Engkos Achmad, M. Rafdi, and Firdaus. "Experimental investigation of vitamin C yield of tomatoes and vitamin $C$ essence by spray drying and dehumidifying the drying air: Product quality and energy consumption." In AIP Conference Proceedings, vol. 2001, no. 1, p. 040007. AIP Publishing LLC, 2018. https://doi.org/10.1063/1.5049990

[8] Solval, Kevin Mis, Srijanani Sundararajan, Luis Alfaro, and Subramaniam Sathivel. "Development of cantaloupe (Cucumis melo) juice powders using spray drying technology." LWT-Food Science and Technology 46, no. 1 (2012): 287-293.

https://doi.org/10.1016/i.lwt.2011.09.017

[9] Rattes, Alysson Leandro Ribeiro, and Wanderley Pereira Oliveira. "Spray drying conditions and encapsulating composition effects on formation and properties of sodium diclofenac microparticles." Powder Technology 171, no. 1 (2007): 7-14.

https://doi.org/10.1016/i.powtec.2006.09.007

[10] Fang, Zhongxiang, and Bhesh Bhandari. "Encapsulation techniques for food ingredient systems." Food Materials Science and Engineering (2012): 320-348.

https://doi.org/10.1002/9781118373903.ch12

[11] Samsudin, M. S. N. B. M. M. S. N. B., Md Mizanur Rahman, and M. A. Wahid. "Sustainable power generation pathways in Malaysia: Development of long-range scenarios." Journal of Advanced Research in Applied Mechanics 24, no. 1 (2016): 22-38.

[12] Goula, Athanasia M., and Konstantinos G. Adamopoulos. "A new technique for spray drying orange juice concentrate." Innovative Food Science \& Emerging Technologies 11, no. 2 (2010): 342-351.

https://doi.org/10.1016/i.ifset.2009.12.001

[13] Bai, Chenguang, Zongwei Han, Haotian Wei, Xiaomei Ju, Xinwei Meng, and Qi Fu. "Simulation study on performance of a dual-source hybrid heat pump unit with alternative refrigerants." Energy and Built Environment 1, no. 1 (2020): 1-10.

https://doi.org/10.1016/i.enbenv.2019.08.004

[14] Drosou, Christina G., Magdalini K. Krokida, and Costas G. Biliaderis. "Encapsulation of bioactive compounds through electrospinning/electrospraying and spray drying: A comparative assessment of food-related applications." Drying Technology 35, no. 2 (2017): 139-162. https://doi.org/10.1080/07373937.2016.1162797

[15] Goh, Li Jin, Mohd Yusof Othman, Sohif Mat, Hafidz Ruslan, and Kamaruzzaman Sopian. "Review of heat pump systems for drying application." Renewable and Sustainable Energy Reviews 15, no. 9 (2011): 4788-4796. https://doi.org/10.1016/j.rser.2011.07.072

[16] Jeyaprakash, S., D. C. Frank, and R. H. Driscoll. "Influence of heat pump drying on tomato flavor." Drying Technology 34, no. 14 (2016): 1709-1718. https://doi.org/10.1080/07373937.2016.1174937

[17] Zheng, X., R. Z. Wang, and Y. D. Tu. "Investigation on energy consumption of desiccant coated heat exchanger based heat pump: Limitation of adsorption heat of desiccant." Energy Conversion and Management 188 (2019): $473-479$. https://doi.org/10.1016/i.enconman.2019.03.077

[18] Claussen, I. C., T. S. Ustad, I. Str $\oslash$ Mmen, and P. M. Walde. "Atmospheric freeze drying-A review." Drying Technology 25, no. 6 (2007): 947-957. https://doi.org/10.1080/07373930701394845

[19] Sarkar, J., Souvik Bhattacharyya, and M. Ram Gopal. "Transcritical CO2 heat pump dryer: Part 2. Validation and simulation results." Drying Technology 24, no. 12 (2006): 1593-1600. https://doi.org/10.1080/07373930601030945

[20] Kosasih, Engkos A., and Nanang Ruhyat. "Combination of Electric Air Heater and Refrigeration System to Reduce Energy Consumption: A Simulation of Thermodynamic System." International Journal of Technology 2 (2016): 288295.

https://doi.org/10.14716/ijtech.v7i2.3004

[21] Kosasih, Engkos Achmad, Warjito, Imansyah Ibnu Hakim, and N. Ruhyat. "Use of a double condenser in a dehumidifier with a spray dryer for vitamin A extraction in tomato as a heat-sensitive material." In AIP Conference Proceedings, vol. 1855, no. 1, p. 020008. AIP Publishing LLC, 2017. https://doi.org/10.1063/1.4985453 
[22] Ruhyat, Nanang, and Engkos Achmad Kosasih. "Low energy-specific consumption of refrigerants for combination of electric air heater and refrigeration system using double condensers: A simulation of thermodynamic system." In AIP Conference Proceedings, vol. 2062, no. 1, p. 020063. AIP Publishing LLC, 2019. https://doi.org/10.1063/1.5086610

[23] Al-Sulaiman, Faleh A., and P. Gandhidasan. "Energy analysis of liquid desiccant based evaporative cooling system." In ASME International Mechanical Engineering Congress and Exposition, vol. 42118, pp. 3-12. 2005. https://doi.org/10.1115/IMECE2005-79163

[24] Kosasih, Engkos Achmad, Harinaldi Harinaldi, and Ramon Trisno. "Characteristics of vortex ring formation by synthetic jet actuators in different cavities." International Journal of Technology 7, no. 2 (2016): 296-305. https://doi.org/10.14716/ijtech.v7i2.2986

[25] Lee, Y. K. "The use of nanofluids in domestic water heat exchanger." Journal of Advanced Research in Applied Mechanics 3, no. 1 (2014): 9-24.

[26] Ruhyat, Nanang, Engkos Achmad Kosasih, and I. H. Warjito. "Combination System of Spray Dryer and Low Evaporator Temperature Refrigeration for Drying Vitamine B1." Journal of Advanced Research in Fluid Mechanics and Thermal Sciences 55, no. 1 (2019): 102-110.

[27] Abano, E. E., H. Ma, and W. Qu. "Influence of air temperature on the drying kinetics and quality of tomato slices." Journal of Food Processing \& Technology 2, no. 5 (2011): 2-9. 